\title{
Modern onderwijs en de verantwoordelijkheid van de student
}

Wie een beetje wil meepraten over hedendaags onderwijs moet terloops termen kunnen laten vallen als activerend onderwijs, constructivisme, contextgerelateerd leren, problem-based learning, zelfsturing, formatieve toetsing, competenties. Studenten 'krijgen geen onderwijs' maar 'worden in hun leerproces begeleid'. Dit alles wordt wel samengevat onder de term Nieuw Leren. ${ }^{1}$ Je zult niet meteen alles begrijpen, maar om mee te kunnen doen in de discussie, helpt het als je ze kent. Wat je vooral bij blijft is dat de student centraal staat en dat hij of zij zelfstandig moet leren. Hedendaagse medische curricula vertonen veel kenmerken die passen bij deze termen, dus er is genoeg gespreksstof. Er worden minder hoorcolleges en meer kleinschalig, probleemgestuurd onderwijs gegeven en studenten worden vaker getoetst, niet alleen bij schriftelijke tentamens maar ook op andere manieren. En discussie is ook nodig en logisch, want ook in moderne curricula loopt lang niet alles op rolletjes.

Zo besloot de examencommissie van de opleiding geneeskunde te Utrecht (CRU'99), na behoorlijk wat discussie, met ingang van 2004-2005 tot het grotendeels afschaffen van individuele beoordelingen bij werkgroeponderwijs en tot het facultatief stellen van tussentoetsen in het blokonderwijs - wie meedoet krijgt ze meegeteld; wie niet meedoet moet het van de eindtoets hebben. Waarom? (1) Omdat er regelmatig studenten slaagden die zonder meetellen van werkgroeppunten zouden zijn gezakt voor het blok - voor de examencommissie moeilijk verteerbaar; (2) omdat er geklaagd was dat werkgroepbeoordelingen nogal afhankelijk waren van de persoon van de docent. Studenten met een toevallig strengere groepsdocent en nét onvoldoende punten om te slagen voor het blok voelden zich door het systeem gedupeerd en (3) omdat tussentoetsen docenten veel energie kosten en ook studenten iedere drie weken een toets nogal schools vinden. De algemene gedachtegang van de examencommissie was: studenten zijn volwassen en het past bij modern onderwijs dat studenten zelfstandig zijn en verantwoordelijk voor hun eigen gedrag. Ze komen wel naar de werkgroepen omdat die nuttig zijn en ze hebben een verplichte tussentoets niet nodig.

Langzamerhand worden de gevolgen van het beleid zichtbaar. De deelname aan werkgroeponderwijs neemt af. De deelname aan tussentoetsen neemt af. De studielast voor de meeste blokken is minder en ook het slaagpercentage voor de meeste blokken is afgenomen, ondanks een mildere zak-slaaggrens $(5,6)$ in vergelijking met de voorgaande jaren $(6,0)$. Dat is teleurstellend voor de examencommissie; een teken dat de huidige studentengeneratie toch niet zo volwassen is als we zouden mogen verwachten.

Welke les kunnen we leren? De afschaffing van werkgroeppunten en het facultatief stellen van tussentoetsen heeft kennelijk over de breedte een negatief effect gehad. Meer in het algemeen: maatregelen op het terrein van toetsing beïnvloeden het studeergedrag. Toetsing en beoorde- 
ling vormen kennelijk een instrument met knoppen waarmee het effect van een curriculum sterk wordt bepaald. Wie een curriculum vorm geeft kan niet genoeg aandacht besteden aan de toetsing. ${ }^{2}$ In een recent, fraai artikel in Medical Education betogen Van der Vleuten en Schuwirth zelfs dat assessment eerder moet worden gezien als een instrument voor 'instructional design' dan als een meetinstrument. ${ }^{3}$ Dat is een zienswijze waar veel in zit.

Maar hoe zit dat dan met die schoolsheid? Zijn studenten geneeskunde dan zo weinig gemotiveerd en zelfstandig dat zij een schoolse aanpak nodig hebben? En contrasteert dat niet met de aanpak van dat Nieuwe Leren dat tegenwoordig al in het studiehuis wordt ingezet, de probleemgestuurde benadering, het contextgerelateerde onderwijs en de constructivistische filosofie, waarin veel meer verantwoordelijkheid bij de lerende wordt gelegd? Kortom, alles wat onderwijs modern maakt?

Nee, zo eenvoudig is het niet. In de Volkskrant van zaterdag 5 maart 2005 wordt van leer getrokken tegen de toepassing van dat Nieuwe Leren in het vwo, waarbij de leraar gereduceerd is tot een procesbegeleider of minder eerbiedig: tot een google-assistent. ${ }^{4}$ De kritiek komt van onderwijskundigen, die vooral beleidsmakers er vandoor zien gaan met al te versimpelde onderwijstheorieën. Die zoeken naar "moderne" onderwijsmethoden, op zoek naar oplossingen voor problemen die eigenlijk niet goed zijn gedefinieerd. De indruk wordt regelmatig gewekt alsof bepaalde onderwijsmethoden beter passen bij deze tijd, en alsof studenten tegenwoordig ander onderwijs nodig hebben dan vroeger.

Ik geloof daar niets van. Onderwijs is niet 'modern' of 'ouderwets' in de modieuze zin van het woord. Wel effectief of minder effectief. Dat neemt niet weg dat er nieuwe vondsten, onderzoek of theorieen boven water kunnen komen die vruchtbaarder en overtuigender lijken dan wat er tot dan toe in het onderwijs plaatsvond. ${ }^{5}$ Dan is modern wat anders modieus.

En soms zijn vondsten ook helemaal niet zo nieuw. Dat toetsing een uiterst effectief middel is om studiegedrag te reguleren lijkt nu via een grote omweg weer onder de aandacht te komen. Maar iedereen die zelf een studie heeft gevolgd weet dat natuurlijk al lang. Onderwijs van die charismatische, begaafde docent is misschien beter in het geheugen blijven hangen dan al het gezwoeg in de dagen voor het tentamen. Maar waarom was dat onderwijs zo boeiend? Oók omdat je wist dat je de stof op tentamen moest kunnen reproduceren! Dat motiveert enorm. En een enthousiasmerende docent helpt als je de stof er goed en snel in wil krijgen en vast wil houden. Het is maar de vraag of je met net zoveel plezier de tijd zou vrijmaken om al dat interessante onderwijs te volgen als je er geen tentamen of diploma mee zou behalen.

Het is belangrijk dat onderwijsinstellingen en docenten een sturende functie vervullen, door toetsing, beoordeling of op andere manieren. Dat mag best vertaald worden in verplichtingen voor de studenten. Externe sturing en verplichtingen zijn eenvoudig nodig en vormen een krachtig instrument om het leerproces in goede banen te leiden, mits zij nauw aansluiten bij doelen van het onderwijs. Ook kan dat prima gepaard gaan met contextgerelateerd leren, een constructivistische visie of probleemgestuurd onderwijs. ${ }^{6} \mathrm{Je}$ moet als student gevraagd worden productie te leveren, met deadlines, en daarop beoordeeld worden. Verplichtingen - waaronder toetsing en beoordeling en verplichte onderwijsdeelname - worden te vaak beschouwd als strijdig met volwas- 
sen, modern onderwijs. In de Utrechtse context: werkgroeppunten en regelmatige toetsen zijn misschien zo slecht nog niet in de eerste jaren van de studie. Of, zoals ik regelmatig studenten heb horen zeggen, "het is wel schools voor een universitaire studie, maar in mijn geval toch wel een goede stok achter de deur".

Wat te doen met de klachten over de beoordelingsmethoden? Die verdienen analyse en aanpassing, niet afschaffing. Wie het 'nieuwe leren' zo interpreteert dat de moderne student eigenlijk alles zelf moet doen en weinig sturing nodig heeft, heeft de terminologie toch niet helemaal begrepen. Het kind dreigt dan met het badwater weggegooid te worden.

\section{Olle ten Cate}

\section{Literatuur}

1. Simons RJ, Linden J van der, Duffy T. New learning. Dordrecht: Kluwer Academic Publishers; 2000.

2. Cate ThJ ten. Valide medisch onderwijs [oratie]. Universiteit Utrecht; 1999.

3. Vleuten CPM van der, Schuwirth LWT. Assessing professional competence: from methods to programmes. Med Educ 2005;39:309-17.

4. Giessen P, Schöttlelndreier M. Nieuw leren is hard leren - kritiek neemt toe op leermethoden waarin kinderen zelf mogen kiezen. De Volkskrant 5 maart 2005; p $1 \mathrm{~K}$.

5. Hart I. Best evidence medical education (BEME). Med Teach 1999;21(5):453-4.

6. Cate ThJ ten, Snell L, Mann KV, Vermunt J. Orienting teaching toward the learning process. Acad Med 2004;79(3):219-28. 